Tersedia online di: http://ejournal-balitbang.kkp.go.id/index.php/bawal
e-mail:bawal.puslitbangkan@gmail.com
BAWAL wIDYA RISET PERIKANAN TANGKAP
Volume 9 Nomor 3 Desember 2017
e-ISSN: 2502-6410
NAWALr Akreditasi: 620/AU2/P2MI-LIPI/03/2015

\title{
PARAMETER POPULASI LOBSTER BAMBU (Panulirus versicolor) DI PERAIRAN SIMEULUE
}

\section{POPULATION PARAMETERS OF GREEN LOBSTER/BABOO LOBSTER (Panulirus versicolor) IN THE WATERS OF SIMEULUE}

\author{
Helman Nur Yusuf*1, Ali Suman ${ }^{1}$, Thomas Hidayat ${ }^{1}$ dan Anthony Sisco Panggabean ${ }^{1}$ \\ 1Balai Riset Perikanan Laut, Cibinong, Bogor, Jl. Raya Bogor KM. 47 Nanggewer Mekar, Cibinong-Jawa Barat, Indonesia \\ Teregistrasi I tanggal: 03 April 2017; Diterima setelah perbaikan tanggal: 29 Desember 2017; \\ Disetujui terbit tanggal: 05 Januari 2018
}

\begin{abstract}
ABSTRAK
Lobster bambu (Panulirus versicolor) merupakan komoditas perikanan penting yang telah diekspolitasi di perairan Simeulue. Peningkatan permintaan dan pengusahaan lobster menyebabkan tekanan penangkapan terhadap populasi lobster semakin intensif dan tidak terkendali. Untuk itu diperlukan informasi tentang biologi reproduksi dan parameter populasi lobster dalam rangka pengelolaan sumberdaya lobster yang berkelanjutan. Penelitian dilaksanakan pada Mei sampai dengan Desember 2015 diperairan Simeulue dengan tujuan untuk mengestimasi parameter populasi lobster bambu. Pengamatan dan pengukuran lobster dilakukan di tempat pengumpul lobster dengan sistem sampling acak (random sampling). Analisis data parameter populasi menggunakan software FiSAT (Stock Assessement Tools). Dari hasil penelitian diperoleh bahwa kondisi lobster bambu jantan dan betina tidak seimbang $(1: 1,5)$, pola pertumbuhan bersifat alometrik negatif dengan nilai b sebesar 2,924 dan rata-rata pertama kali tertangkap $(\mathrm{Lc})=86 \mathrm{mmCL}$. Laju pertumbuhan $(\mathrm{K})=0,320$ per tahun dan panjang karapas asimtotik $(\mathrm{CL} \infty)$ 149,1 $\mathrm{mm}$. Laju mortalitas alami $(\mathrm{M})=0,99$ per tahun, laju kematian akibat penangkapan (F) sebesar 0,84 per tahun dan laju kematian total (Z) sebesar 1,83 per tahun. Tingkat eksploitasi (E) sebesar 0,46 atau pemanfaatan sumberdaya lobster bambu belum optimum. Penambahan baru dalam populasi berlangsung sepanjang tahun dan mencapai puncaknya pada Juni dan Juli bersamaan dengan musim timur. Untuk itu perlu adanya regulasi pemerintah dalam pengelolaan perikanan lobster yang berkelanjutan dengan menerapkan close season lobster pada puncak musim pemijahan.
\end{abstract}

Kata Kunci: Panulirus versicolor; parameter populasi; Simeulue

\begin{abstract}
The painted green/bamboo lobster (Panulirus versicolor) is an important fish commodities that have been exploited in the waters of Simeulue. Increased utilization and uncontrolled exploitation of lobster causing pressure on the lobster population. For this reason, there is a need for information about the parameters of the lobster population in the management for the sustainability of lobster resource. The experiment was conducted in May to December 2015 Simeulue waters for the purpose of estimating the population parameters lobster green. Sampel collected randomly in the lobster landing site. Analysis of the data using FiSAT II software (FAOICLARM Stock Assessement Tools). The results obtained unbalanced condition of green lobster (1:1.5), the growth pattern is allometrically negative with value b of 2,924, length at fish first caught $(L c)=86 \mathrm{~mm} \mathrm{CL}$. The lobster growth rate $(K)=0,320$ per year and asymptotic carapace length $\left(C L_{\infty}\right) 149.10 \mathrm{~mm}$. The rate of natural mortality $(M)=0.99$ per year, the mortality rate due to the arrest of $(F)$ of 0.84 per year and total mortality rate $(Z)$ of 1.83 per year. The rate of exploitation $(E) 0,46$ or green lobster resource was not optimum. Recruitment occur throughout the year with peak recruitment in June and July of the southeast monsoon. A government regulation is needed for the sustainable management of lobster resources by applying a close season during the peak spawning peri.
\end{abstract}

Keywords: Panulirus versicolor; population parameters; Simeulue 


\section{PENDAHULUAN}

Lobster merupakan salah satu komoditas ekspor perikanann Indonesia dan tertangkap di perairan Indonesia. Data ekspor-impor pemerintah Indonesia mencatat bahwa lobster termasuk dalam kelompok perikanan udang. Perairan Simeulue dan sekitarnya merupakan salah satu daerah potensial penangkapan lobster di Samudera Hindia bagian Barat Sumatera. Daerah penyebaran lobster di perairan Indonesia sangat luas, meliputi daerah karang, pantai dan teluk, dengan luas perairan karang Indonesia sekitar $68.000 \mathrm{~km}^{2}$, dan potensi udang karang sebesar 4.128 ton per tahun (Suman et al. 1993). Subani (1971) menyatakan bahwa sebaran Panulirus versicolor di Indonesia yaitu di Pulau Tinjil, Palabuhanratu, Selat Sunda, Teluk Betung, Teluk Semangka, Bali Selatan (Benoa dan Negara), Sumatera dan Kepulauan Seribu. Perairan Simeulue merupakan salah satu wilayah penyebaran udang lobster yang potensial, daerah penangkapan lobster terbentang di seluruh perairan Simeulue.

Losbter yang tertangkap di perairan Indonesia diperkirakan ada 4 jenis yaitu lobster bambu (Panulirus versicolor), lobster batu ( $P$. penicilatus), lobster batik ( $P$. longipes) dan lobster mutiara (P. ornatus) (Suman et al., 1993). Jenis lobster bambu umumnya hidup pada perairan terumbu karang yang terlindung diantara batu karang dan jarang dalam kelompok yang berjumlah besar (Subani, 1984). Berdasarkan data statistik perikanan tangkap Simeulue, bahwa proporsi hasil tangkapan lobster batu sekitar 37\%, lobster bambu 32\%, lobster batik 19\% dan $12 \%$ lobster mutiara (DKP Simeulue, 2016).

Perikanan lobster mempunyai peluang besar untuk ditingkatkan karena mempunyai nilai ekonomis tinggi baik regional maupun internasional (Setyono, 2006). Atas dasar tersebut, perlu adanya pengelolaan sumberdaya dan regulasi pemerintah dalam pengusahaan sumberdaya, dimana sesuai dengan PERMEN-KP 56 (2016) pasal 2, bahwa penangkapan lobster hanya dapat dilakukan dengan ketentuan ukuran panjang karapas lebih besar dari $8 \mathrm{~cm}$ atau bobot lebih besar dari 200 gram per ekor.

Pengusahaan lobster di wilayah ini dimulai sejak 2005 pasca sunami 2004. Produksi udang lobster berdasarkan statistik perikanan tangkap Kabupaten Simeulue mengalami tren fluktuasi, produksi tahun 2009 sebesar 24,67 ton, 2010 sebesar 17 ton, 201133 ton, 2012 sebesar 18 ton, 2013 sebesar 17 ton, 2014 sebesar 40 ton dan tahun 2015 sebesar 25 ton atau rata-rata sebesar 23,97 ton pertahun (DKP Simeulue, 2016). Dalam kaitan tersebut perlu dikaji kondisi populasi lobster bambu (Panulirus versicolor) di perairan Simeulue sebagai dasar pengelolaannya secara berkelanjutan.

\section{BAHANDANMETODE}

Pengumpulan data panjang dan biologi dilakukan selama periode April sampai Desember 2015 dari hasil tangkapan nelayan di perairan Simeulue, dengan mengunakan jaring lobster dan menangkap langsung mengunakan sarung tangan (manual). Pengamatan parameter populasi yang diamati seperti nisbah kelamin, ukuran pertama kali matang gonad pertumbuhan, mortalitas, ukuran pertama kali tertangkap, pola rekruitmen dan tingkat pemanfaatan. Ukuran panjang lobster ditentukan dengan jangka sorong (caliper) yaitu dari bagian tengah supra orbital sampai ke bagian tengah posterior karapas (Sparre \& Venema, 1999). Untuk mengukur berat individu lobster digunakan timbangan digital dengan ketelitian 1 gram. Sedangkan musim pemijahan ditentukan dari persentase sebaran temporal lobster yang bertelur.

Penentuan jenis kelamin ditentukan berdasarkan ciri morfologi lobster seperti yang dikemukakan oleh Prescott (2000) dan Chan (2000). Kematangan gonad lobster didasarkan pada ciri kematangan secara fungsional yaitu dengan mengamati lobster betina yang membawa telur/ egg bearing female/ ovigerous (MacDiarmid \& SainteMarie 2006). Sebaran frekuensi panjang karapas diperoleh dengan mentabulasikan data panjang karapas dalam tabel distribusi frekuensi dengan selang kelas $5 \mathrm{~mm}$. Data yang diperoleh yaitu panjang karapas, berat dan jenis kelamin lobster.

\section{Analisis Data}

Untuk mengetahui perbandingan kelamin (sex ratio) maka dilakukan uji- $\mathrm{X}^{2}$ (chi square) dengan digunakan rumus Effendie (2002) sebagai berikut:

$$
\mathrm{X}^{2}=\sum_{\mathrm{i}=1}^{\mathrm{k}} \frac{(\mathrm{Oi}-\mathrm{Ei})^{2}}{\mathrm{Ei}}
$$

dimana;
$\mathrm{X}^{2}=$ chi square
$\mathrm{Oi}=$ frekuensi udang yang diobservasi
$\mathrm{Ei}=\begin{aligned} & \text { frekuensi udang betina dan jantan yang } \\ & \text { diharapkan }\end{aligned}$

Uji-t dengan taraf nyata $95 \%$ dan derajat bebas (n-1) dengan hipotesis:
$\mathrm{H}_{0}$ : tidak ada perbedaan yang nyata antara jumlah jantan dan betina
$\mathrm{H}_{1}$ : terdapat perbedaan yang nyata antara jumlah jantan dan betina
Jika t-hitung lebih kecil dari t-tabel $\left(\mathrm{t}_{\mathrm{hit}}<\mathrm{t}_{\mathrm{tab}}\right)$ maka terima $\mathrm{H}_{0}$ tolak $\mathrm{H}_{1}$.
Jika t-hitung lebih besar dari t-tabel $\left(\mathrm{t}_{\text {hit }}>\mathrm{t}_{\text {tab }}\right)$ maka terima $\mathrm{H}_{1}$ tolak $\mathrm{H}_{0}$


Analisa hubungan panjang karapas dan berat lobster dilakukan dengan menggunakan persamaan eksponensial sebagai berikut (Lagler, 1972, Jennings et al 2001):

$\mathrm{W}=\mathrm{aL}^{\mathrm{b}}$

dimana;

$\mathrm{W}=$ berat lobster (gram)

$\mathrm{L}=$ panjang lobster $(\mathrm{mm})$

$\mathrm{a}=$ intersep (perpotongan kurva hubungan panjang berat dengan sumbu Y)

$\mathrm{b}=$ slope (kemiringan)

Nilai b sebagai penduga tingkat keeratan hubungan panjang berat lobster:

a. Nilai $b=3$, maka pertumbuhan ikan isometrik artinya pertumbuhan panjang sebanding dengan pertumbuhan berat $\left(\mathrm{W} \approx \mathrm{L}^{3}\right)$.

b. Nilai $b<3$, maka perumbuhan ikan alometrik negatif artinya pertumbuhan panjang lebih cepat dibandingkan pertumbuhan berat $\left(\mathrm{W}<\mathrm{L}^{3}\right)$.

c. Nilai b>3, maka pertumbuhan ikan alometrik positif artinya pertumbuhan berat lebih cepat dari pada pertumbuhan panjang $\left(\mathrm{W}>\mathrm{L}^{3}\right)$.

Uji-t (uji parsial) untuk menguji nilai dengan hipotesa (Steel \& Torie, 1993 dalam Effendie, 1997):

$\mathrm{H}_{0}: \quad \mathrm{b}=3$ (isometrik)

$\mathrm{H}_{1}: \quad \mathrm{b} \neq 3$ (alometrik)

Jika t-hitung lebih kecil dari t-tabel $\left(\mathrm{t}_{\text {hit }}<\mathrm{t}_{\text {tab }}\right)$ maka terima $\mathrm{H}_{0}$ tolak $\mathrm{H}_{1}$.

Jika t-hitung lebih besar dari t-tabel $\left(\mathrm{t}_{\mathrm{hit}}>\mathrm{t}_{\mathrm{tab}}\right)$ maka terima $\mathrm{H}_{1}$ tolak $\mathrm{H}_{0}$

Pendugaan rata-rata panjang pertama kali matang gonad (length at first maturity) dilakukan sesuai dengan prosedur penghitungan yang dilakukan Udupa (1986):

$\mathrm{m}=\mathrm{Xk}+\frac{\mathrm{X}}{2}-\left(\mathrm{X} \sum \mathrm{pi}\right)$

dimana;

$\mathrm{m}=\log$ ukuran ikan saat pertama matang ovarium

$\mathrm{Xk}=\log$ ukuran lobster dimana $100 \%$ ikan sampel sudah matang

$\mathrm{X}=$ selang log ukuran (log size increment)

$\mathrm{Pi}=$ proporsi ikan matang pada kelompok ke-i

Rata-rata ukuran ikan pertama matang ovarium diperoleh dari nilai antilog $(\mathrm{m})$

Pendugaan ukuran ikan/lobster pertama kali tertangkap dilakukan dengan membuat grafik hubungan antara distribusi panjang kelas (sumbu $\mathrm{X}$ ) dengan jumlah ikan yang dinyatakan dengan distribusi normal kumulatif estimasi (sumbu Y). Untuk memperoleh nilai Lc (length at first capture) yaitu dengan menarik garis hubungan antara sumbu X dan sumbu Y untuk nilai 50\% (Sparre \& Venema, 1999).

$$
\begin{aligned}
\mathrm{S}_{\mathrm{L}} \text { est } & =\frac{1}{1+\exp \left(\mathrm{S}_{1}-\mathrm{S}_{2} * \mathrm{~L}\right)} \\
\mathrm{L} 50 \% & =\frac{\mathrm{S} 1}{\mathrm{~S} 2} \ldots \ldots \ldots \ldots \ldots \ldots \ldots \ldots \ldots \ldots \ldots \ldots \ldots \ldots \ldots
\end{aligned}
$$

dimana;

SL $=$ frekwensi kumulatif dari proporsi tertahan

$\mathrm{L} 50 \%=$ panjang/tinggi badan dimana $50 \%$ dari tenggiri tertahan

$\mathrm{S}_{1} \& \mathrm{~S}_{2}=$ konstanta pada rumus kurva logistik berbasis panjang

$\mathrm{S}_{1} \quad=$ intersep a (perpotongan antara garis linear dengan sumbu y)

$\mathrm{S}_{2} \quad=$ slope $\mathrm{b}$ (sudut kemiringan garis regresi)

Analisa pertumbuhan panjang karapas infinitive $\left(\mathrm{L}_{\infty}\right)$ dan laju pertumbuhan $(\mathrm{K})$ diduga dengan mengunakan ELEFAN dalam FiSAT II (Gayanilo et al., 2005). Perhitungan pertumbuhan dengan persamaan Von Bertalanffy sebagai berikut (King, 1995):

$\mathrm{L}_{\mathrm{t}}=\mathrm{L} \infty\left(1-\mathrm{e}^{[-\mathrm{K}(\mathrm{t}-\mathrm{to})]}\right)$

dimana;

$\mathrm{L}_{\mathrm{t}} \quad=$ panjang karapas pada saat umur (satuan waktu)

$\mathrm{L}_{\infty}=$ panjang karapas asimtotik secara teoritis

$\mathrm{K}=$ koefisien pertumbuhan (per satuan waktu)

$\mathrm{t}_{0}=$ umur teoritis pada saat panjang karapas nilai dengan nol

Pendugaan umur teoritis $\left(\mathrm{t}_{0}\right)$ dilakukan dengan persamaan empiris Paully (1980):

$\log (-$ to $)=-0,3922-0,2752 \log (\operatorname{L} \infty)-1,038 \log (K)$

Mortalitas alami (M) diduga dengan menggunakan rumus empiris Pauly (1980). Pauly menjelaskan bahwa ada pengaruh suhu rata-rata perairan (T) terhadap laju mortalitas dengan rumus yang digunakan:

$$
\begin{array}{r}
\log M=-0,00066-0,2792 \quad \log L \infty+0,6543 \\
\log K \quad+0,4634 \quad \log T \quad \ldots \ldots \ldots . . . . . .(\quad 7)
\end{array}
$$

Pendugaan mortalitas total (Z) dilakukan dengan metode kurva konversi hasil tangkapan dengan panjang (length convereted catch curve) dalam program FiSAT II (Gayanilo et al, 2005). Perhitungan tingkat pemanfaatan (E) diperoleh dari nilai dugaan mortalitas alami (M) dan mortalitas penangkapan (F), nilai tersebut digunakan dengan persamaan: 


$$
\begin{aligned}
& E=\frac{F}{F+M} \\
& E=\frac{F}{Z} \quad \cdots
\end{aligned}
$$

Analisa pola rekruitmen dengan mengunakan program FiSAT II dimana hasil pendugaan diperoleh dengan memasukkan nilai $\mathrm{L}_{\infty}, \mathrm{K}$ dan $\mathrm{t}_{\mathrm{o}}$

Hasil per penambahan baru lobster bambu dianalisis berdasarkan metode Beverton \& Holt (1957):

$$
\frac{Y}{R}=F * A * W \infty *\left(\begin{array}{l}
\frac{1}{Z}-\frac{3 U}{Z+K}+ \\
\frac{3 U^{2}}{Z+2 K}+\frac{U^{3}}{Z+3 K}
\end{array}\right) \ldots .(10)
$$

Di mana F adalah laju kematian karena penangkapan, $\mathrm{W}_{\infty}$ adalah berat asimptotik ikan, $\mathrm{Z}$ adalah total kematian, $\mathrm{K}$ adalah laju pertumbuhan, Nilai A merupakan hasil dari persamaan

$$
A=\left(\frac{L \infty-L_{C}}{L \infty-L_{r}}\right)^{M / K}
$$

Nilai U diperoleh dari persamaan

$$
\mathrm{U}=1-\frac{\mathrm{L}_{\mathrm{C}}}{\mathrm{L} \infty}
$$

\section{HASIL DAN BAHASAN \\ Hasil}

\section{Nisbah Kelamin}

Analisis perbandingan jenis kelamin lobster bambu sebanyak 1373 ekor , terdiri dari 547ekor jantan dan 826 ekor betina $(1: 1,5)$ dengan persentase $39,83 \%$ jantan dan $60,13 \%$ betina. Berdasarkan uji chi square $\left(\mathrm{X}^{2}\right)$ diperoleh nilai sebesar 71,1. Sedangkan $X^{2}$ tabel $(a=0,05$; $v=6)$ sebesar 12,59. Hasil uji chi square menunjukkan terdapat perbedaan yang nyata antara jumlah lobster jantan dan betina dengan tingkat kepercayaan $95 \%(a=0,05)$ atau dalam kondisi tidak seimbang.

Hasil pengamatan tingkat kematangan gonad (TKG) April - Desember menunjukkan bahwa kondisi matang gonad lobster pada kisaran 9,5\% - 1,5\%, dan tertinggi pada Juni (16,71\%) dan Agustus (15,8\%). Dari hasil pengamatan TKG dapat diprediksi bahwa pemijahan lobster berlangsung sepanjang tahun dan puncaknya pada Juni dan Agustus (Gambar 1).

\section{Panulirus versicolor}

$\mathrm{n}=\mathbf{5 6 2}$

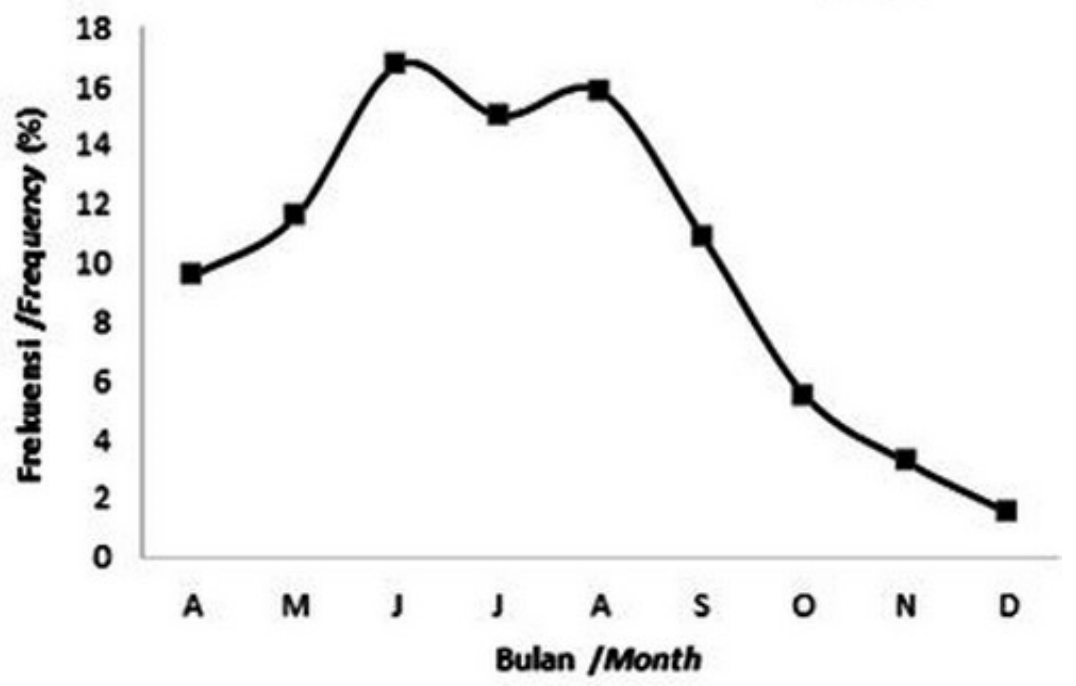

Gambar 1. Sebaran persentase kematangan kelamin lobster bambu (Panulirus versicolor) diperairan Simeulue 2015. Figure 1. Temporal distribution of maturity of scalloped green lobster in Simeulue waters 2015.

\section{Hubungan Panjang Karapas dan Berat Individu}

Hasil simulasi hubungan panjang karapas dan berat lobster jantan menunjukkan bahwa pertumbuhan mengikuti persamaan $\mathrm{W}=0,001 \mathrm{CL}^{2.924}\left(\mathrm{n}=547 ; \mathrm{R}^{2}=0,934\right)$ (Gambar 2 a) dan lobster betina $\mathrm{W}=0,001 \mathrm{CL}^{2.925}(\mathrm{n}=826$;
$\left.\mathrm{R}^{2}=0,890\right)$ (Gambar 2 b). Nilai b lobster jantan dan betina kurang dari 3, dan hasil uji-t terhadap nilai b menunjukkan bahwa hasil tidak berbeda nyata $(\mathrm{n}<0.05)$ baik untuk jantan dan betina sifat pertumbuhannya alometrik negatif, penambahan panjang karapas lobster bambu lebih cepat dibanding pertumbuhan berat. 

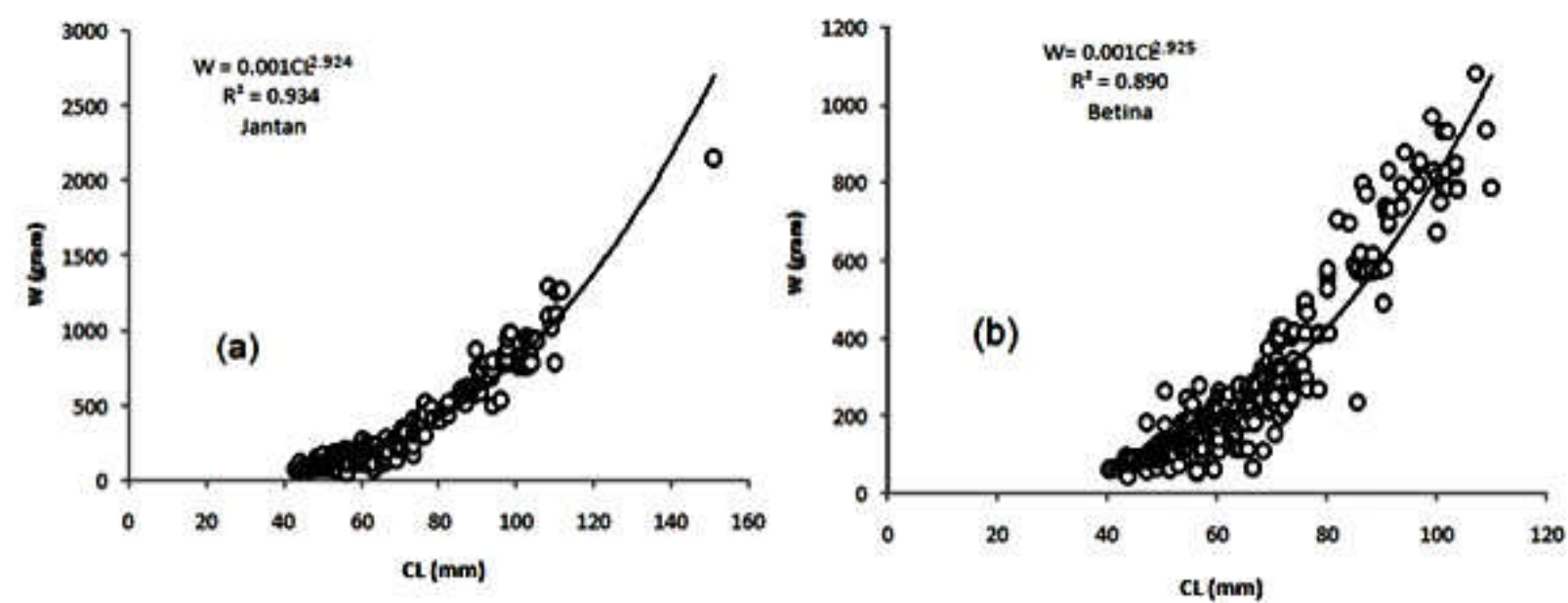

Gambar 2. Hubungan panjang berat Panulirus versicolor jantan (a) dan betina (b) di perairan Simeulue, Juni-Desember 2015.

Figure 2. Length-weight relationship of male (a) and female (b) Panulirus versicolor in Simeulue waters, JuneDecember 2015.

Rata-Rata Ukuran Matang Gonad (Lm) dan Rata-Rata Ukuran Pertama Kali Tertangkap (Lc)

Analisa terhadap lobster pasir betina menunjukkan rata-rata mencapai ukuran matang kelamin (size at 50\% ovigerous) pada panjang karapas $88 \mathrm{~mm}$. Rata-rata ukuran lobster yang tertangkap (Lc50\%) dengan jaring lobster pada panjang karapas $86 \mathrm{~mm}$. Hasil ini menunjukkan bahwa rata-rata ukuran lobster yang tertangkap lebih kecil daripada ukuran pada saat mencapai kematangan gonad (Lc<Lm). Ukuran pertama kali tertangkap (Lc) dengan tingkat porbabilitas $\mathrm{L}_{50 \%}$ pada selektivitas jaring insang dasar (bottom gillnet) melalui estimasi kurva logistik lobster bambu juga diperoleh $\mathrm{Lc}=86 \mathrm{~mm}$ CL (Gambar 3).

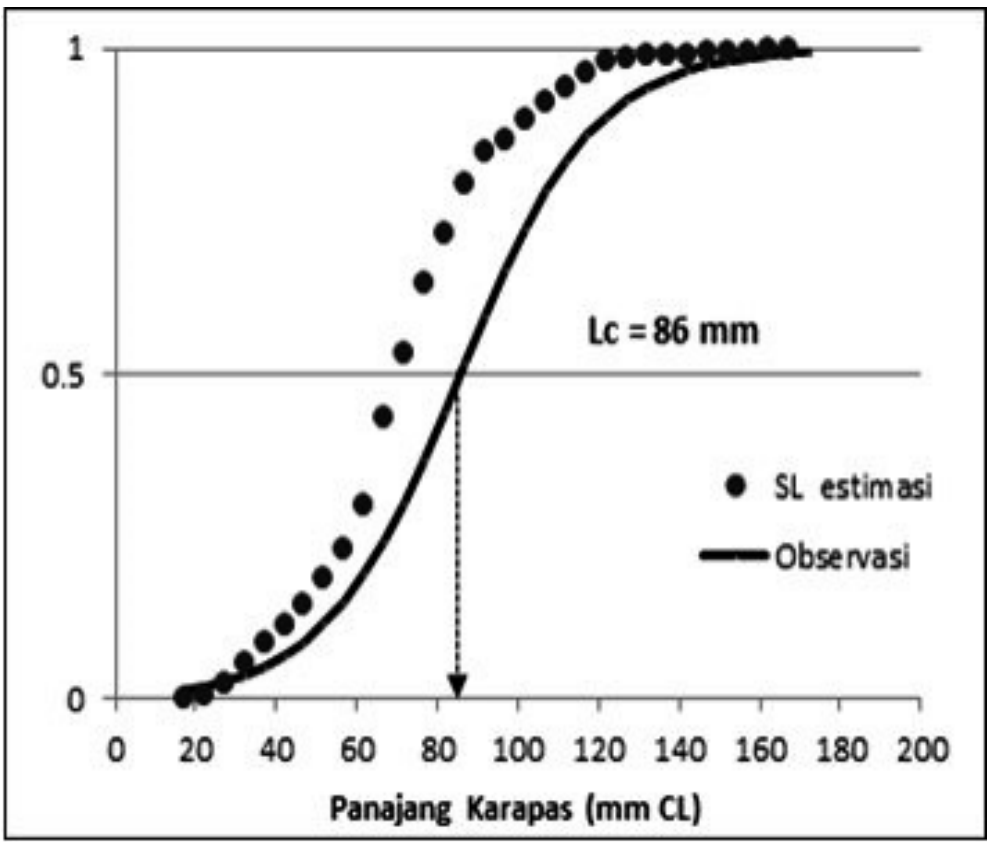

Gambar 3. Rata-rata panjang karapas tertangkap (Lc) lobster bambu (Panulirus versicolor) di peraiaran Simeulue, 2015.

Figure 3. Mean length carapace at capture (Lc) of scalloped spiny lobster in Simeulue waters, 2015.

\section{Pertumbuhan}

Hasil analisa menggunakan program ELEFAN menunjukkan bahwa panjang asimtotik nilai $\mathrm{L}_{\infty}$ lobster bambu sebesar 149,1 mm CL dan nilai K sebesar 0,320. Umur teoritis pada panjang karapas dengan nol $\left(\mathrm{t}_{\mathrm{o}}\right)=$ 0,031. Kurva pertumbuhan lobster bambu di perairan Simeulue pada Gambar 4. 


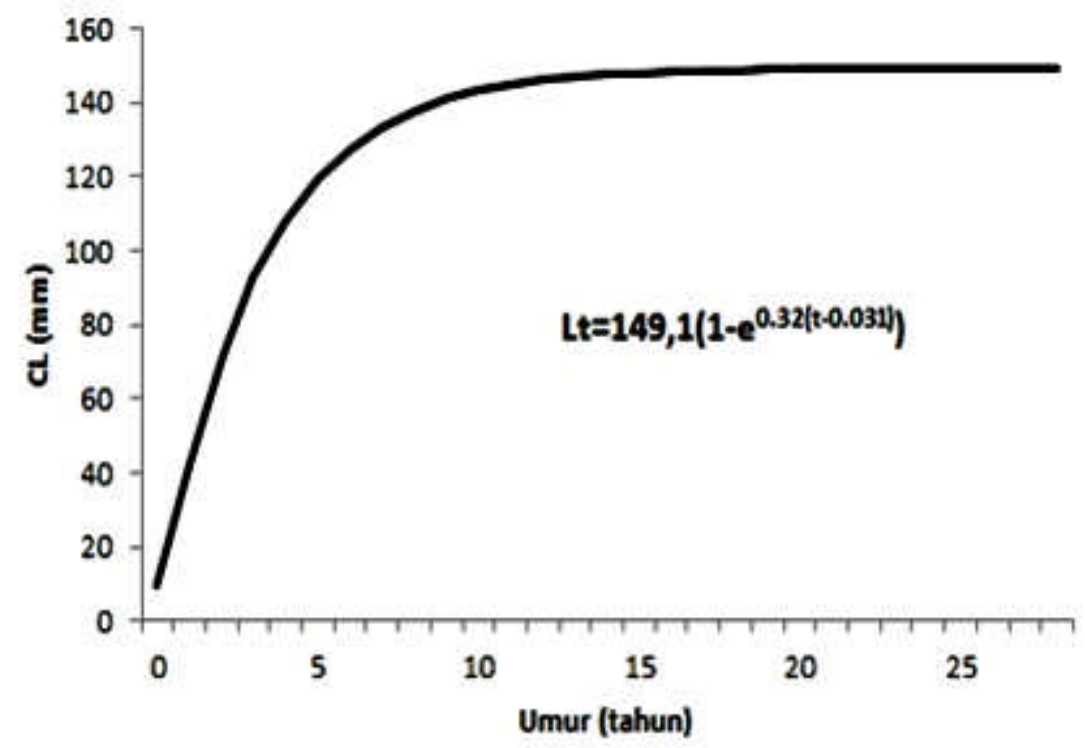

Gambar 4. Kurva pertumbuhan lobster bambu di Perairan Simeulue, 2015.

Figure 4. Growth formula of scalloped spiny lobster in Simeulue waters, 2015.

\section{Mortalitas}

Laju mortaslitas total ditentukan oleh laju kematian alamiah (M) dan laju kematian akibat penangkapan (F). Hasil analisis laju kematian alamiah (M) lobster bambu sebesar 0,99 per tahun dan laju kematian akibat penangkapan (F) sebesar 0,84 per tahun, dan laju kematian total sebesar (Z) 1,83 per tahun. Laju Pengusahaan (E) sebesar 0,46, dimana pengusahaan atau laju ekspolitasi dapat ditingkatkan. Kurva konversi hasil tangkapan dengan panjang (length converted catch curve) pada Gambar 5 .

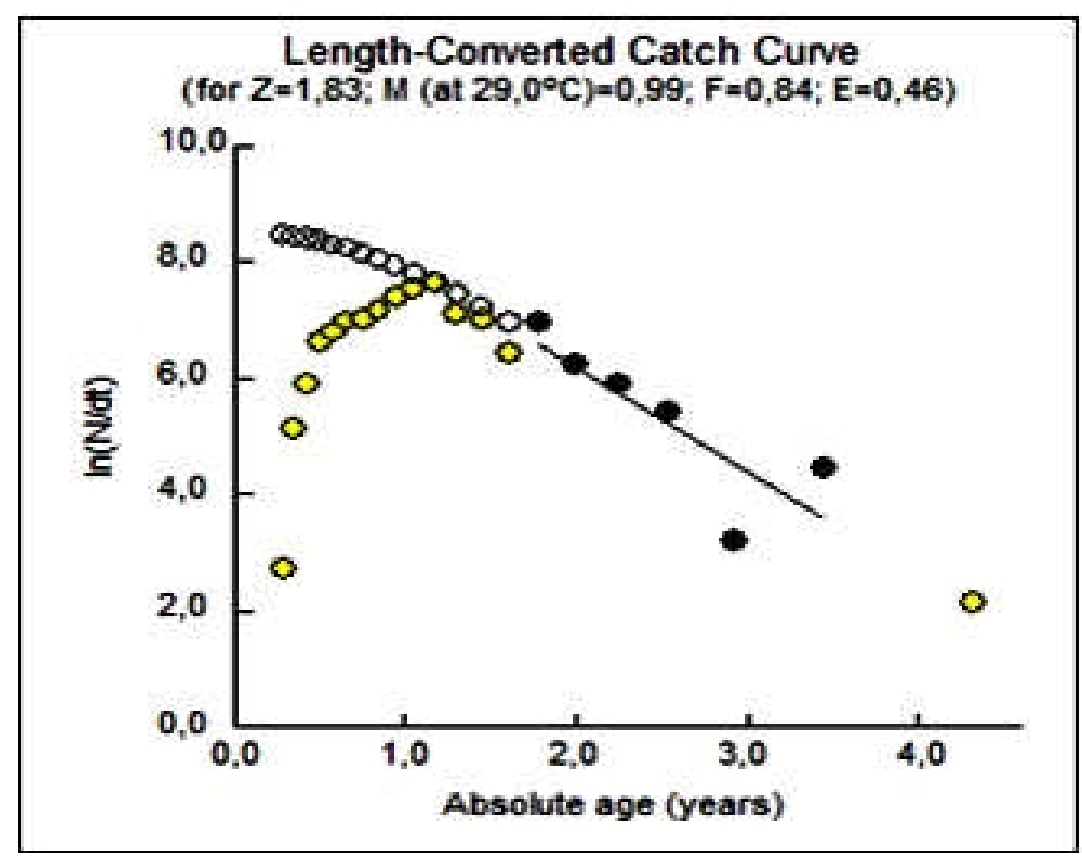

Gambar 5. Kurva hasil tangkapan lobster bambu yang dilinearkan di perairan Simeulue, 2015.

Figure 5. Linierized catch curve of scalloped spiny lobster in Simeulue waters, 2015.

\section{Pola Penambahan Baru (Rekruitmen)}

Pola penambahan baru $P$. versicolor di perairan Simeulue dan sekitarnya terjadi hampir setiap bulan atau sepanjang tahun. Puncak terjadinya penambahan baru terjadi pada Juni sebesar $20.93 \%$ dan Juli sebesar $21.11 \%$. Diduga pada bulan-bulan tersebut puncak terjadinya penambahan baru dalam populasi di daerah penangkapan. Hasil analisis pola penambahan baru pada Tabel 1. 
Tabel 1. Persentase bulanan penambahan baru Panulirus versicolor Table 1. Monthly percentage of new addition of Panulirus versicolor

\begin{tabular}{lc}
\hline Bulan/Month & Rekrutmen (\%)/Recruitment $(\%)$ \\
\hline Januari & 8,88 \\
Februari & 6,47 \\
Maret & 7,22 \\
April & 9,0 \\
Mei & 15,95 \\
Juni & 20,93 \\
Juli & 21,11 \\
Agustus & 2,96 \\
September & 6,06 \\
Oktober & 1,11 \\
November & 0,3 \\
Desember & 0 \\
\hline
\end{tabular}

\section{Bahasan}

Hasil penelitian menunjukkan bahwa nisbah kelamin lobster bambu jantan dan betina relatif tidak seimbang $(1: 1,5)$. Hasil penelitian sebelumnya di perairan Pantai Selatan Pangandaran dan Teluk Ekas - Lombok diperoleh nisbah kelamin yang relatif seimbang (Nuraini \& Sumiono 2008; Junaidi et al., 2010), di perairan Sikka lobster bambu relatif seimbang $(1: 1,09)$ (Ernawati, 2014). Menurut Effendie (2002) variasi nisbah kelamin dapat terjadi karena disebabkan oleh tiga faktor, yaitu perbedaan tingkah laku seks, kondisi lingkungan, dan lokasi penangkapan, kondisi lingkungan cenderung memberikan daya dukung lebih, faktor ekologi, tidak adanya pencemaran pesisir pantai dapat meningkatkan organisme pada wilayah tersebut dan meningkatkan tingkat produksi (Scones, 1993 in Soselisa, 2006). Fenomena ini menunjukkan bahwa berbedanya hasil peneilitian di Simeulue, Sikka dan Teluk Ekas Lombok, mengindikasikan bahwa komposisi jenis lobster bambu di simeulue relatif lebih baik. Hal ini diduga karena tingkat pemanfaatan yang lebih rendah dan ketersedian sumberdaya lobster bambu lebih baik dibanding kedua tempat tersebut.

Hubungan panjang karapas dan berat lobster bambu jantan betina menunjukkan pola pertumbuhan alometrik negatif, dimana pertumbuhan panjang karapas lebih cepat daripada pertambahan berat badan. Ini menunjukkan populasi lobster yang tertangkap pada fase muda, dimana energi lebih diarahkan pada pertumbuhan panjang bukan digunakan untuk penyiapan untuk memijah (pertumbuhan gonad). Kondisi perairan Simelue yang umummnya daerah karang dengan kisaran 1-4 meter pada substrat bebatuan, perairan yang jernih, tidak dipengaruhi arus sungai dan hutan mangrove tumbuh sumbur yang diduga mempengaruhi pola pertumbuhan lobster bambu. Pertumbuhan biologis yang komplek dan faktor lain yang mempengaruhinya, meliputi faktor dalam keturunan, sex, umur, parasit dan penyakit. Faktor keturanan dan sex menunjukkan parameter biologi yang mengindikasikan kualiatas air baik atau tidak dengan terlihat jumlah dan jenis biota yang diperairan (Hardjojo \& Djokosetiyanto, 2005; Effendi, 2003). Faktor luar yang mempengaruhi pertumbuhan utamanya adalah makanan dan suhu perairan (Effendi, 2002). Kedua faktor sangat mempengaruhi karena makanan merupakan daya produksi untuk meningkatkan produktivitas oleh organisme, produktivitas ini mampu merubah laju perubahan energy matahari membentuk senyawa-senyawa organik yang dapat digunakan sebagai bahan pangan (Odum, 1979).

Hasil penelitian serupa dengan jenis yang sama, juga diperoleh dari hasil penelitian di peraira Aceh Barat, perairan pantai Kecamatan Ayah Kabupaten Kebumen, perairan Pangandaran, Cilacap, Teluk Ekas dan Thoothukudi-India, Teluk Pelabuhanratu (Suman, 1994; Hartoyo et al., 2002; Kadafi et al., 2006; Nuraini \& Sumiono, 2008; George \& Morgan, 1979; Junaidi et al., 2010; Vaithesswaraan et al. 2012; Suherman, 2017). Hasil penelitian lain jenis lobster pasir (P. homarus) diperairan Cilacap (Baktiar et al., 2013), perairan Yogyakarta dan Pacitan (Hargiyanto et al., 2013), lobster batu ( $P$. penicilatus) di perairan Pacitan dan Gunung kidul (Fauzi et al., 2013).

Kesamaan pola pertumbuhan tersebut, diduga disebabkan oleh kesamaan karakteristik perairan dalam menunjang ketersediaan makanan dan habitat yang sesuai. Hal ini mengingat pertumbuhan individual bergantung pada ketersedian makanan dan suhu perairan (Monterio \& Oliveira 2002). Kesamaan pola pertumbuhan di beberapa perairan, baik sejenis maupun jenis berbeda dipengaruh oleh kondisi lingkungan perairan terutama suhu dan ketersediaan serta kualitas makanan diperairan yang relatif (Fourzan \& Alvarez, 2003). Menurut Hargiyatno et al., (2013), perbedaaan nilai $\beta$ menunjukkan hubungan 
panjang-bobot yang diakibatkan oleh faktor eksternal dan internal. Faktor eksternal di antaranya adalah musim, kualitas air, suhu, pH, salinitas, posisi geografis, dan teknik sampling (Jenning et al., 2001). Faktor internal meliputi perkembangan gonad, kebiasaan makan, fase pertumbuhan, dan jenis kelamin (Froese 2006; Tarkan et al., 2006).

Rata-rata ukuran pertama kali tertangkap (Lc) lobster bambu ( $P$. versicolor) diperoleh nilai $86 \mathrm{mmCL}$ dengan ukuran matang kelamin (size at 50\% ovigerous) pada panjang karapas $88 \mathrm{~mm}$ LM. Ukuran Lc tersebut lebih besar bila dibanding lobster bambu diperairan utara Sikka dengan Lc 73,67 mmCL (Ernawati, 2014), lobster bambu diperairan Pangandaran dengan Lc sebesar 50,0 mmCL (Nuraini dan Sumiono, 2008), lobster bambu di Teluk Palabuharatu dengan Lc lobster jantan dan betina masing-masing adalah 62,11 mm dan 66,66 mm CL dan di Cilacap sebesar 43,5 mmCL (Bakhtiar et al., 2013), lobster bambu jantan di perairan Inggris sebesar $80 \mathrm{~mm}$ Lc (George \& Morgan, 1979), lobster bambu betina di perairai Palau sebesar 82 mm CL (MacDonald, 1982).

Lobster bambu yang tertangkap di perairan Simeulue lebih besar dari ketentuan pemerintah yaitu Lc $86 \mathrm{~mm} \mathrm{CL}$ dan rata-rata bobotnya sebesar 277, 14 gram. Sedangkan ketentuan pemerintah mengenai ukuran lobster yang boleh ditangkap sebesar $80 \mathrm{~mm}$ atau bobot lebih besar dari 200 gram per ekor berdasarkan PERMEN-KP 56 (2016) pasal 2. Hal ini menunjukkan bahwa rata-rata ukuran pertama kali tertangkap lobster bambu perairan Simeulue dan sekitarnya relatif lebih besar dibanding ketentuan pemerintah, diperairan Sikka, perairan selatan Jawa dan perairan yang di teliti. Kondisi ini diduga karena tekanan penangkapan dan pengusahaan lobster bambu lebih rendah dibanding perairan lainnya. Pengukuran ini penting dalam pengelolaan perikanan mengingat bahwa eksploitasi harus mampu membiarkan sejumlah tertentu induk-induk ikan/udang/lobster yang seukuran atau lebih dari ukuran tersebut pada saat mencapai kematangan (Sudjastani, 1974).

Laju pertumbuhan $(\mathrm{K})$ lobster sebesar 0,320 per tahun dan panjang asimtotik nilai $\mathrm{L}_{\infty}$ lobster bambu sebesar 149,10 mm CL, hasil penelitian di perairan Sikka berbeda diperoleh $\mathrm{K}$ sebesar 0,44 pertahun dan pencapai panjang karapas infinitif $(\mathrm{CL} \infty)$ lobster bambu sebesar 146,7 mm CL(Ernawati et al., 2014), hasil penelitian di perairan Teluk Pelabuhanratu adanya kesamaan hasil yang diperoleh nilai $\mathrm{K}$ sebesar 0,3 untuk lobster bambu jantan dan betina 0,29, dengan panjang asimtotik nilai $\mathrm{L} \infty$ lobster bambu jantan sebesar 95 mm CL dan betina 90 mm CL (Suherman, 2017). Hasil penelitian oleh Fatah (2004) di Kabupaten Kebumen dan sekitarnya menunjukkan bahwa nilai $\mathrm{K}$ sebesar 0,6 per tahun dan panjang karapas asimtotiknya $\left(\mathrm{L}_{\infty}\right)$ sebesar 107 mm. diperairan Great Barrier Reef Australia sebesar
K sebesar 0,27 per tahun dengan panjang karapas infinitif $\left(\mathrm{CL}_{\infty}\right)$ sebesar 144,7 mmCL (Frisch, 2007), kisaran panjang karapas asimtotik $\left(\mathrm{L}_{\infty}\right)$ sekitar 118-164 mm; K, 0,27-0,54 tahun-1 (Phillips et al., 1992; Pitcher, 1993; Skewes et al., 1997), sedangkan lobster mutiara (Panulirus ornatus) di Torres Strait Australia nilai K sebesar 0,157 per tahun dengan panjang karapas infinitif $\left(\mathrm{CL}_{\infty}\right)$ sebesar 150,7 mmCL (Philips et al., 1992).

Perbedaan hasil penelitian di diduga karena perbedaan karakteristik lingkungan perairan, seperti di Indonesia adalah wilayah dan Australia sub tropis. Pertumbuhan lobster di wilayah tropis cenderung lebih cepat dibanding sub tropis, disebabkan diantaranya oleh suhu perairan ditropis relatif stabil dibanding sub tropis (Philips, 2006). Perbedaan nilai-nilai parameter pertumbuhan yang diperoleh, juga dipengaruhi oleh perbedaan ukuran sampel yang dianalisis, periode pengambilan sampel, kelimpahan makanan, dan kondisi lingkungan (Bakhtiar et al., 2013). Menurut Morgan (1980) bahwa pertumbuhan dipengaruhi oleh beberapa faktor antara lain makanan, suhu dan densitas. Suman et al., (1993) menyatakan bahwa perairan Indonesia mempunyai iklim tropis dan mempunyai suhu rata-rata $28^{\circ} \mathrm{C}$, sebaliknya perairan sub tropis perubahan suhu relatif ekstrim sehingga dapat menghambat metabolisme dan pertumbuhan hewan air.

Sumberdaya lobster yang hidup di perairan tropis mempunyai nilai $\mathrm{K}$ lebih tinggi dibandingkan dengan perairan yang dingin. Nilai K juga terkait dengan metabolik udang yang merupakan suatu fungsi temperatur (Mahasin 2003). Pertumbuhan merupakan proses biologis yang komplek dengan berbagai faktor yang mempengaruhinya antara lain faktor dalam (intrinsict) dan luar (extrinsict). Faktor dalam meliputi keturunan, jenis kelamin, umur, parasit, dan penyakit. Faktor luar yang mempengaruhi pertumbuhan utamanya adalah makanan dan suhu perairan (Effendie 2002). Selanjutnya Heibo et al., (2005) mengatakan bahwa secara umum hewan air tumbuh lebih cepat dengan penurunan lintang disuatu wilayah karena perubahan suhu terhadap metabolisme relatif stabil.

Laju kematian alamiah (M) lobster bambu sebesar 0,99 per tahun, laju kematian akibat penangkapan (F) sebesar 0,84 per tahun, dan laju kematian total sebesar (Z) 1.83 per tahun. Laju Pengusahaan (E) sebesar 0,46. Kondisi tersebut menjelaskan bahwa laju penangkapan atau upaya penangkapan lebih kecil terhadap laju kematian alamiah. Terlihat nilai $\mathrm{F}$ lebih tinggi dari nilai $\mathrm{M}$ yang berpengaruh terhadap laju eksploitasi (E). Laju eksploitasi atau pengusahaan lobster bambu sebesar 0,46. Hasil penelitian (Suherman, 2017) diperoleh nilai mortalitas alami (M) jantan dan betina adalah 0,59 dan 0,57 per-tahun. Tren produksi dan upaya mortalitas lobster jantan dan betina akibat penangkapan (F) masing-masing 0,70 dan 0,51 pertahun, sehingga tingkat pemanfaatan (exploitation rate, 
E) masing-masing adalah 0,54 dan 0,47 per-tahun. Gulland (1971) menyatakan bahwa suatu stok sudah mencapai pengusahaan optimal jika nilai E optimal $\left(\mathrm{E}_{\text {opt }}\right)$ adalah 0,5. Penggunaan nilai $\mathrm{E} \sim 0,5$ sebagai nilai optimal untuk rasio pengusahaan suatu stok, dengan asumsi bahwa hasil seimbang $\mathrm{F}=\mathrm{M}$, dan tingkat eksploitasi lobster bambu belum optimum atau belum melebihi nilai E yang optimal. Artinya bahwa sumberdaya lobster bambu belum mencapai kondisi overfishing. Hal tersebut terlihat dari rata-rata produksi udang lobster dari tahun 2009-2015 sebesar 23,97 ton dan adanya tren peningkatan produksi. Atas dasar tersebut perlunya pengelolaan dengan mempertahankan jumlah upaya yang ada saat ini, dan perlu adanya pusat data yang memfasilitasi tersedianya data yang respresentatif sehingga diharapkan data tersebut dapat memberikan informasi yang tepat.

Penambahan baru atau rekruitmen adalah bertambahnya individu-individu baru ke suatu daerah penangkapan (cacthabel area) (Beverton dan Holt, 1957 dalam King, 1995). Penambahan baru diduga terjadi pada Juni dan Juli atau musim timur. Penelitian Panulirus versicolor di perairan teluk Palabuhanratu dengan puncak pada Oktober untuk lobster jantan dan Juli untuk lobster betina (Suherman, 2017). Penelitian rekruitmen jenis lobster bambu yang sama, dilaporkan bahwa puncak rekruitmen di perairan utara Kabupaten Sikka terjadi pada bulan Agustus dan September (Ernawati et al., 2014). Perbedaan puncak rekruitmen lobster diduga karena perbedaan pola dan upaya penangkapan dimasing-masing perairan yang dipengaruhi oleh perubahan cuaca. Penelitian P. Homarus di perairan Cilacap dengan puncak pada Juni (Baktiar $e t$ al., 2013) dan Pangandaran pada April dan Oktober (Suman et al., 1993). Perbedaan puncak rekruitmen lobster diduga karena perbedaan pola penyebaran dan upaya penangkapan di setiap wilayah perairan yang dipengaruhi oleh perubahan cuaca. Hasil penelitian Suradi (2009) di perairan Kebumen bahwa ukuran panjang karapas ratarata lobster yang tertangkap termasuk dalam kategori sangat kecil sehingga mengarah pada kondisi growth overfishing, karena hampir tidak ada kesempatan bagi lobster untuk tumbuh menjadi ukuran yang layak tangkap

\section{KESIMPULAN}

Nisbah kelamin lobster bambu (Panulirus versicolor) jantan dan betina di perairan Simuelue dalam kondisi tidak seimbang. Hubungan panjang berat lobster bambu jantan dan betina bersifat allometrik negatif. Ukuran rata-rata matang gonad (Lm) sebesar $88 \mathrm{~mm}$ dan rata-rata ukuran pertama kali tertangkap (Lc) sebesar $86 \mathrm{mmCL}$. Laju pengusahaan (E) sebesar 0,46 yang menunjukkan belum optimum. Untuk itu perlu adanya regulasi pemerintah dalam pengelolaan perikanan lobster yang berkelanjutan dengan menerapkan close season lobster pada puncak musim pemijahan yaitu pada Juni dan Juli.

\section{PERSANTUNAN}

Tulisan ini merupakan bagian dari kegiatan penelitian "Karakteristik Biologi Perikanan, Habitat Sumberdaya dan Potensi Produksi Sumberdaya Ikan di WPP 572 Sumatera Bagian Barat 2015" yang di selenggarakan oleh Balai Penelitian Perikanan Laut Muara Baru Jakarta.

\section{DAFTAR PUSTAKA}

Bakhtiar, N. M., Solichin, A., \& Saputra, S. W. (2013). Pertumbuhan dan laju mortalitas lobster batu hijau (Panulirus homarus) di perairan Cilacap Jawa Tengah. Universitas Diponegoro Journal of Maquares. 2(4), $1-10$.

Beverton, R. J. H., \& Holt S. J. (1957). On the dynamics of exploited fish populations. Fish Invest. U.K. Ministry of Agriculture, Food and Fisheries, London

Chan, T. Y. (2000). Lobster. In Living Marine Resourcesof the Western Central Pacific. Vol. 2. Cephalopods, crustacean, holothurians, and sharks. FAO Species Identification Guide for Fishery Purposes. FAO-UN, Norwegian Agency for International Development, 974-1043.

[DKP] Dinas Kelautan dan Perikanan. (2016). Statistik Dinas Kelutan dan Perikanan Kabupaten Simuelue tahun 2015.47 p.

Effendie, M. I. (2002). Biologi Perikanan. Yayasan Pusataka Nusantara. Yogyakarta: 163 p.

Ernawati, T., Kembaren, D., Suprapto, \& Sumiono, B. (2014). Parameter populasi lobster bambu (Panulirus versicolor) di perairan utara Kabupaten Sikka dan sekitarnya. Bawal. Widya Riset Perikanan Tangkap, 6(3), 169-175.

Fatah, M. D. (2004). Bioekonomi udang karang (Panulirus spp.) pada usaha perikanan tangkap skala kecil di Kabupaten Kebumen dan sekitarnya. [Tesis]. Program Pasca Sarjana. Universitas Diponegoro. Semarang.

Fauzi, M., Prasetyo, A. P., Hargiyanto, I. T., Satria, F., \& Utama, A. A. (2013). Hubungan panjang berat dan faktor kondisi lobster batu (P. penicilatus) di perairan selatan Gunung Kidul dan Pacitan. BAWAL, 5 (2), $97-$ 102.

Fourzan, P. B., \& Alvarez, E. L. (2003). Factor affecting growth of the spiny lobsters Panulirus gracilis and Panulirus inflatus (Decapoda: Palinuridae) in Guerrero, Mexico. Rev. Biol. Trop, 51 (1), 165-174. 
Frisch, A. J. (2007). Grwoth and reproduction of the painted spiny lobster (Panulirus versicolor) on the Great Barrier Reef (Australia). Fisheries Research, 85, 6167.

Gayanilo, F. C., Sparre, Jr., \& Paully, D. (2005). The FAOICLARM stock assessment tools II (FISAT II). Revised Version. User's Guide. FAO Comput. Inf. Ser. Fish.8, $168 \mathrm{p}$.

Gulland, J. A. (1971). The Fish Resources of the Ocean. Fishing News (Books) Ltd. West Byfleet England, 255p.

Hargiyatno, I. T., Satria, F., Utama, A. A., \& Fauzi, M. (2013). Hubungan panjang berat dan faktor kondisi lobster pasir (Panulirus homarus) di perairan selatan Gunung Kidul dan Pacitan. BAWAL, 5 (1), 41-48.

Hartoyo, P., Sukardi \& Mulia, D. S. (2002). Evaluasi potensi udang karang "spiny lobster" (Panulirus spp.) di perairan Cilacap. Sains Akuatik. Jurnal Ilmu-Ilmu Perairan. Fakultas Perikanan dan Ilmu Kelautan.Universitas Muhammadiyah Purwokerto, 5556.

Jennings. S., Kaiser, M., \& Reynolds, J. D. (2001). Marine Fisheres Ecology. Alden Pres Ltd. Blackwell Publishing. United Kingdom, 417 pp.

Junaidi, M., Cokrowati, N., \& dan Abidin, Z. (2010). Aspek reproduksi lobster (Panulirus sp.) di perairan Teluk Ekas Pulau Lombok. Jurnal Kelautan, 3 (1), 29-36.

Heibo, E., Magnhagen, C., \& Vollestad, L. A. (2005). Latitudinal variation in lifehistory traits in Eurasian perch. Ecology, 86, 3377-3386.

Kadafi, M., Widaningroem, R., \& Soeparno. (2006). Biological aspects and maximum sustainable yield of spiny lobster (Panulirus spp.) in Ayah coastal waters Kebumen regency. Journal of Fisheries Sciences VIII (1): 108-117.

King, M. (1995). Fishery Biology, Assesment and Management. United Kingdom. Fishing News Books, $341 \mathrm{p}$.

MacDiarmid, A. B., \& Sainte-Marie ,B. (2006). Reproduction. Dalam B.F. Phillips (Ed.) Lobsters : Biology, Management, Aquaculture and Fisheries. Blackwell Publishers, p. 45-77.

MacDonald, C. D., 1982. Catch composition and reproduction of the spiny lobster Panulirus versicolor at Palau. Trans. Am. Fish. Soc. 111, 694-699
Mahasin, M. Z. (2003). Kajian stok dan bioekonomi lobster (Panulirus spp.) untuk menunjang pemanfaatan berkelanjutan di Propinsi Daerah Istimewa Yogyakarta. [Tesis]. Program Pasca Sarjana. Universitas Diponegoro. Semarang

Morgan, G. R. (1980). Population dynamics of spiny lobster. In Cobb JS \& Bruce FP. The biology and management of lobster II, Academic Press, New York.189-217.

Nuraini, S, \& Sumiono, B. (2008). Parameter biologi udang barong di pantai selatan Pangandaran, Jawa Barat. Prosiding Seminar Nasional Tahun V Hasil Penelitian Perikanan dan kelautan. Universitas Gadja Mada, 14 hal.

Odum, E. P. (1979). Dasar-Dasar Ekologi. Edisi Ketiga. Gadjah Mada University Press. Oreginal English Edition. Fundamental of Ecology Thurd Edition, Yokyakarta.

[PERMEN-KP] Peraturan Menteri Kelautan Dan Perikanan Republik Indonesia 56. (2016). Larangan Penangkapan dan / atau Pengeluaran Lobster (Panulirus spp.), Kepiting (Scylla spp.), dan Rajungan (Portunus spp.) Dari Wilayah Negara Republik Indonesia.

Philips, B. F., Palmer, M. J., Cruz, R., \& Trendall, J. T. (1992). Estimating growth of the spiny lobsters Panulirus cygnus, $P$. argus and P. ornatus. Australian Journal of Marine and Freshwater Research, 43, 1117-88.

Philips, B. F. (2006). Lobster: Biology, management, aquaculture and fisheries. Departement of Enviromental Biology, Muresk Institute, Curtin University of Technology, Australia, pp 11-43.

Pitcher, C. R. (1993). Spiny lobster. In: Wright, A., Hill, L. (Eds.), Nearshore Marine Resources of the South Paciûc. Forum Fisheries Agency, Honiara, pp. 539607.

Prescott, J. (2000). A Handbook for lobster fisherman o fthe tropical pacific islands. South Pacific Commission, Noumea, New Caledonia. 20p.

Pauly, D. (1980). On interrelationships between natural mortality, growth parameters and mean environmental temperature in 175 fish stocks. J. Cons. CIEM, 39 (3), 175-192.

Setyono, D. E. D. (2006). Budidaya Pembesaran Udang Karang (Panulirus spp.). Oseana, 31(4), 39-48.

Skewes, T. D., Pitcher, C. R, \& Dennis, D. M. (1997). Growth of ornate rock lobsters, Panulirus ornatus, in Torres Strait, Australia. Mar. Freshw. Res. 48, 497-501. 
Soselisa, A. 2006. Pengelolaan Kawasan Pesisirda Laut Gugusan Pulau-Pulau Padaido, Distrik Padaido, Kabupaten Biak Numfor, Papua (Desertasi). Bogor Program Pengelolaan Sumberdaya Pesisir Dan Lautan PPs-IPB. 258 hal.

Sparre, P., \& Venema, S. C. (1999). Introduksi pengkajian stok ikan tropis. Pusat Penelitian dan Pengembangan Perikanan. Buku 1. Manual. Terjemahan dari: Introduction to Tropical Fish Assesment Part I. FAO Fish Tech Pap, 306(I), 438p.

Subani, W. (1971). Perikanan udang barong (Spiny lobster) di Indonesia. Direktorat Jendral Perikanan Jakarta.27 hal.

Subani, W. (1981). Penelitian lingkungan hidup udang barong (spiny lobster), perikanan dan pelestarian sumberdaya di pantai selatan Bali. Bulletin Penelitian Perikanan. I, 361-386.

Subani, W. (1984). Studi mengenai pergantian kulit udang barong (Spiny lobster), (Panulirus spp) kaitannya dengan hasil tangkapan. Jurnal Penelitian Laut No. 30 Jakarta. Hal 99-105.
Suman, A., Rijal, M., \& Subani, W. (1993). Pengusahaan sumberdaya udang karang di perairan Aceh Barat. Jurnal Penelitian Perikanan Laut. Balai Penelitian Perikanan Laut Jakarta, 8, 84-90.

Suman, A., W. Subani, W., \& Prahoro, P. (1994). Beberapa Parameter Biologi Udang Pantung (Panulirus humarus) di Perairan Pangandaran Jawa Barat. Jurnal Penelitian Perikanan Laut, (85).1-8.

Tarkan, A. S., Gaygusuz, O., Acipinar, P., Gürsoy, C., \& Ozulug, M. (2006). Length-weight relationship of fishes from the Marmara region (NW-Turkey). Journal of Applied Ichthyology. 22(4):271-273.

Udupa, K. S. (1986). StatisticaL method of estimating the size of first maturity in fish. Fishbyte ICLARM. Manila. Vol 4(2). 8-1. 